\title{
cJun and CREB2 in the Postsynaptic Neuron Contribute to Persistent Long-Term Facilitation at a Behaviorally Relevant Synapse
}

\author{
Jiang-Yuan $\mathrm{Hu},{ }^{1}$ Amir Levine, ${ }^{1}$ 일. Ju Sung, ${ }^{2}$ and Samuel Schacher ${ }^{1}$ \\ ${ }^{1}$ Department of Neuroscience, Columbia University College of Physicians and Surgeons, New York State Psychiatric Institute, New York, New York 10032 \\ and ${ }^{2}$ The Commonwealth Medical College, Department of Basic Sciences, Scranton, Pennsylvania 18509
}

Basic region leucine zipper (bZIP) transcription factors regulate gene expression critical for long-term synaptic plasticity or neuronal excitability contributing to learning and memory. At sensorimotor synapses of Aplysia, changes in activation or expression of CREB1 and CREB2 in sensory neurons are required for long-term synaptic plasticity. However, it is unknown whether concomitant stimulus-induced changes in expression and activation of bZIP transcription factors in the postsynaptic motor neuron also contribute to persistent long-term facilitation (P-LTF). We overexpressed various forms of CREB1, CREB2, or cJun in the postsynaptic motor neuron L7 in cell culture to examine whether these factors contribute to P-LTF. P-LTF is evoked by 2 consecutive days of 5-HT applications (2 5-HT), while a transient form of LTF is produced by 1 day of 5-HT applications (1 5-HT). Significant increases in the expression of both cJun and CREB2 mRNA in L7 accompany P-LTF. Overexpressing each bZIP factor in L7 did not alter basal synapse strength, while coexpressing cJun and CREB2 in L7 evoked persistent increases in basal synapse strength. In contrast, overexpressing cJun and CREB2 in sensory neurons evoked persistent decreases in basal synapse strength. Overexpressing wild-type cJun or CREB2, but not CREB1, in L7 can replace the second day of 5-HT applications in producing P-LTF. Reducing cJun activity in L7 blocked P-LTF evoked by 25 -HT. These results suggest that expression and activation of different bZIP factors in both presynaptic and postsynaptic neurons contribute to persistent change in synapse strength including stimulus-dependent long-term synaptic plasticity.

Key words: Aplysia; cell culture; persistent synaptic plasticity; postsynaptic neuron; sensorimotor synapse; transcription factors

\section{Introduction}

Activity-dependent changes in the activation and expression of basic region leucine zipper (bZIP) transcription factors contribute to transcription-dependent long-term memory (Hughes and Dragunow, 1995; Yin et al., 1995; Lonze and Ginty, 2002; Carlezon et al., 2005; Mohamed et al., 2005; Alberini, 2009; Kandel, 2012) and to their cellular analogs: LTP or facilitation (LTF), LTD, or long-term changes in excitability (Dash et al., 1990; Alberini et al., 1994; Zhou et al., 2009; Gruart et al., 2012). Brain region- and cell-specific activations of CREB1, C/EBP, CREB2 and cJun, and their activators or repressors contribute to the induction and maintenance of long-term plasticity (Bartsch et al., 1995, 1998; Deisseroth et al., 1996; Davis et al., 2000; Sanyal et al., 2002; Chen et al., 2003; Pittenger et al., 2006; Alberini, 2009;

\footnotetext{
Received Aug. 8, 2014; revised 0ct. 15, 2014; accepted Nov. 10, 2014.

Author contributions: J.-Y.H. and S.S. designed research; J.-Y.H., A.L., and Y.-J.S. performed research; J.-Y.H., A.L., Y.-J.S., and S.S. analyzed data; J.-Y.H. and S.S. wrote the paper.

This research was supported by National Institutes of Health (NIH) Grant MH 060387. Animals were provided by the National Center for Research for Aplysia at the University of Florida in Miami, which is supported by NIH Grant RR-10294. We thank Dr. Wayne Sossin for providing constructs and Yang Chen for preparing cell cultures.

The authors declare no competing financial interests.

Correspondence should be addressed to Jiang-Yuan Hu, Department of Neuroscience, Columbia University College of Physicians and Surgeons, New York State Psychiatric Institute, 1051 Riverside Drive, New York, NY 10032. E-mail: jh2004@columbia.edu.

DOI:10.1523/JNEUROSCI.3284-14.2015

Copyright $\odot 2015$ the authors $\quad 0270-6474 / 15 / 350386-10 \$ 15.00 / 0$
}

Zhou et al., 2009; Sargin et al., 2013), and to the induction, consolidation, and reconsolidation of long-term memory (Lamprecht et al., 1997; Kida et al., 2002; Josselyn et al., 2004; Han et al., 2007, 2009; Mamiya et al., 2009; Glyvuk et al., 2010; Alberini and Chen, 2012; Tubon et al., 2013; Kim et al., 2014). However, it is not known whether the same or different transcription factors in both elements of a synapse-presynaptic and postsynaptic neurons - contribute to persistent long-term synaptic plasticity.

In Aplysia, CREB1, CREB2, C/EBP, and their respective binding partners contribute to the induction and consolidation of LTF and LTD in sensorimotor synapses (Dash et al., 1990; Kaang et al., 1993; Alberini et al., 1994; Bartsch et al., 1995, 1998, 2000; Guan et al., 2002, 2003; Upadhya et al., 2004; Fiovarante et al., 2008; Liu et al., 2008, 2011; Rajasethupathy et al., 2012) that contribute directly toward long-term sensitization or habituation of withdrawal reflexes (Kandel, 2012). These studies focused exclusively on the activation (phosphorylation or dephosphorylation), expression (transcriptional and post-transcriptional regulation) of the bZIP factors, and their downstream consequences on effector genes in the presynaptic sensory neuron. However, changes in protein expression and other cellular responses in the postsynaptic motor neuron contribute to LTF or LTD (Wu and Schacher, 1994; Zhu et al., 1997; Villareal et al., 2007; Cai et al., 2008; Fulton et al., 2008), suggesting that bZIP transcription factors in the postsynaptic motor neuron might impact gene expres- 


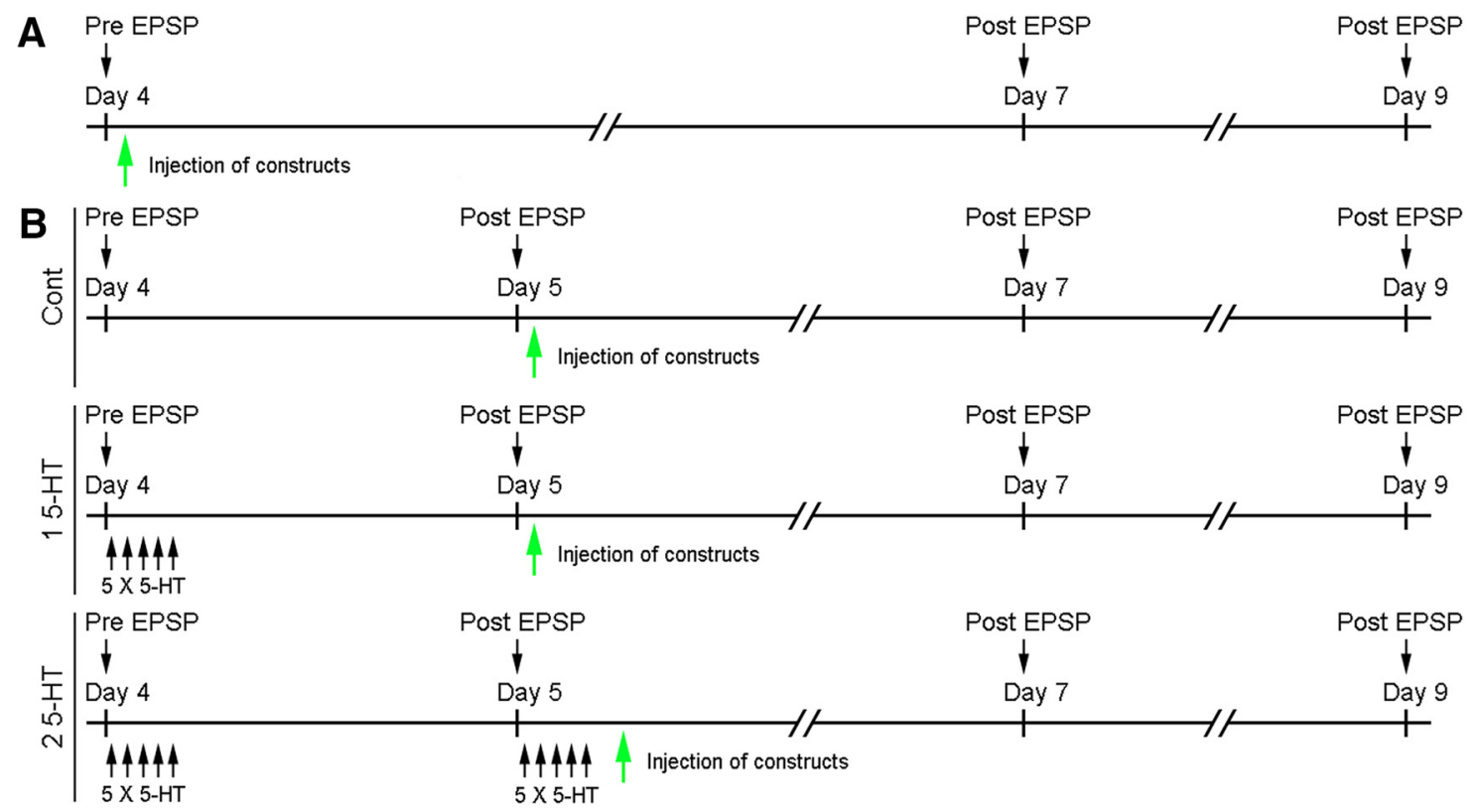

Figure 1. Experimental time lines used to monitor persistent changes in synapse strength evoked by 5 -HT applications or by altering expression or activity of various bZIP factors in L7. EPSPs were recorded before (day 4, Pre-EPSP) and after (days 5, 7, and 9, Post-EPSP) control treatments ( $\boldsymbol{A}$ and top of $\boldsymbol{B}$ ), one set of 5-HT applications (15-HT; middle section of $\boldsymbol{B}$ ), or two sets of 5-HT treatments (25-HT; bottom). 5 - HT treatments ( 5 bath applications of $5 \mu \mathrm{m} 5$-HT each lasting 5 min and separated by 15 min intervals) on day 4 (15-HT) or on days 4 and 5 ( 25 - HT) were applied to cultures. At the designated time points (green arrows on day 4 or day 5) various constructs (see text for details) were injected into L7.

sion and contribute to long-term plasticity. We therefore addressed the question: Do bZIP transcription factors in the postsynaptic motor neuron contribute to persistent LTF (P-LTF; lasting $>7 \mathrm{~d}$ ) evoked by repeated brief applications of 5-HT (Hu et al., 2011; Hu and Schacher, 2014)?

We found that cJun and CREB2 expression/activity in the postsynaptic neuron L7 contributes to P-LTF. Thus, the increase in expression/activation of CREB1 and decrease in expression of CREB2 in sensory neurons plus the increase in expression/activation of cJun and CREB2 in L7 contribute to persistent plasticity at this behaviorally relevant synapse. The results suggest that different transcription factors work in tandem to regulate presynaptic and postsynaptic functions to establish a new synaptic homeostasis following stimuli that evoke persistent long-term plasticity.

\section{Materials and Methods}

Cell culture and electrophysiology. Sensory neurons were isolated from pleural ganglia dissected from adult animals (60-80 g; Aplysia californica, which are hermaphrodite) and motor neuron L7s were isolated from juvenile abdominal ganglia $(2 \mathrm{~g})$ and maintained in coculture for up to $9 \mathrm{~d}$ (Hu et al., 2011). The coculture contained one sensory neuron and one L7. Standard electrophysiological techniques were used to record EPSP amplitudes evoked in L7. L7s were held at $-80 \mathrm{mV}$ and EPSP amplitudes were recorded before and after various treatments at the indicated time points (Fig. 1). Each sensory neuron was stimulated with a brief depolarizing pulse to evoke an action potential using an extracellular electrode placed near the cell body of the sensory neuron. Cultures with initial EPSP amplitudes in the range of $10-40 \mathrm{mV}$ were used $(90 \%$ of total cultures) for control and experimental conditions. Assignment of any culture to control and experimental groups was to ensure that there were no significant differences in the mean and variance for basal synapse strengths between the groups before treatments. Cultures were maintained at $18^{\circ} \mathrm{C}$ and fed every other day with medium containing $50 \%$ filtered hemolymph and 50\% L15.

$P$-LTF. P-LTF lasting more than a week was evoked as reported previously (Hu et al., 2011). After recording the baseline strength of sensorimotor synapses on day 4 , some cultures were exposed to 2 consecutive days (2 5-HT) of five applications of 5-HT ( $5 \mu \mathrm{M}$; Sigma) each lasting 5 min at $20 \mathrm{~min}$ intervals (Fig. 1) to evoke P-LTF. Some cultures were exposed to $1 \mathrm{~d}$ of such 5-HT applications (1 5-HT) on day 4 to evoke a more transient form of LTF lasting up to $3 \mathrm{~d}$. Each application of 5-HT was washed out with solution containing 50\% seawater and 50\% L15. On day 5, L7s in some cultures with $25-\mathrm{HT}$ treatments were injected with constructs $6 \mathrm{~h}$ after the second set of 5-HT applications. In other cultures, constructs were injected into L7s on day 5 after 15 -HT treatment or control given on day 4 (Fig. 1). Control cultures received mock treatments. EPSP amplitudes were re-examined on day 5 before second 5-HT applications or injections of constructs, and on days 7 and 9.

Cloning wild-type and mutant forms of cJun. Degenerate oligonucleotide primers were used to amplify a cJun cDNA fragment near its transactivation domain from cDNA derived from the CNS of Aplysia. The resulting PCR product was cloned into pCR2.1 (Life Technologies) and subsequently confirmed by sequencing. The $5^{\prime}$ end and $3^{\prime}$ end of the cDNA were then cloned using $5^{\prime}$ RACE and $3^{\prime}$ RACE, respectively. A Marathon cDNA Amplification kit (BD Clontech) was used to generate cDNA from Aplysia CNS poly (A+) RNA according to the manufacturer's instructions. The final PCR product was sequenced and the open reading frame of cJun was deposited in the GenBank under accession number JX228175.1. The S54 to A54 cJun mutant was constructed on the template of cJun by oligonucleotide site-directed mutagenesis using the QuikChangeXL Site-Directed Mutagenesis kit (Agilent Technologies). The mutation was confirmed by DNA sequencing.

Plasmid construction and microinjection. Constructs: the pNEX3 enhanced green fluorescent protein CREB1 (CREB1-eGFP) and cJun (cJun-eGFP), and the pNEX3 enhanced yellow fluorescent protein CREB2 (CREB2-eYFP) were made as described previously (Manseau et al., 2001). Microinjection was executed by a pneumatic PicoPump (PV820; World Precision Instruments). Solution of constructs $(0.3$ $\mu \mathrm{g} / \mu \mathrm{l}$ DNA in distilled water) containing $0.2 \%$ fast green was microinjected into sensory neuron or L7 nuclei on day 4 or day 5 . The tip of the micropipette was inserted into the cell nucleus. Short pressure pulse (20-50 ms duration; 20-40 psi) was delivered until the nucleus of the sensory neuron became uniformly green (Hu et al., 2010). Because the volume of the nucleus in L7 is $\sim 30 \times$ that of the nucleus of the sensory neuron, pressure pulse (20-40 psi) of 600-1200 ms was delivered until the nucleus of L7 became uniformly green. In some cases, cJun-eGFP and 
CREB2-eYFP constructs were coinjected into either L7s or sensory neurons on day 4 . The fluorescent images of construct expression were captured with a Nikon Diaphot microscope.

Dissection of cellular compartments and RT$P C R$. Pleural-pedal ganglia were dissected from 60 to $80 \mathrm{~g}$ animals, rinsed in L15 seawater, and processed as described below. Sensorimotor cocultures were rinsed with hemolymphfree medium ( $1: 1$ by volume of $L 15$ plus Instant Ocean Water) and allowed to cool to $4^{\circ} \mathrm{C}$ for 20 min, before the cell body of L7 was collected (Schacher et al., 1999). Each sample was transferred to $200 \mu \mathrm{l}$ of TRIzol (Invitrogen), and total RNA was isolated after chloroform extraction and isopropanol precipitation and the RNA was reverse transcribed by using a SuperScript III First-Strand Synthesis kit (Invitrogen). The amount of cDNA was quantified using realtime PCR (qRT-PCR). The primers that were used to amplify specific cDNA regions of the transcripts were c-jun: 5'-TCGTAATCGCG TTGCAGCTA-3' and 5'-TGC AATTCT TTCGAGCTTTCG-3', creb1: 5'-AGCGGC CTTGTTGTTTGG-3' and $5^{\prime}$-GCCACGT CAAAATACACCATCA-3', creb2: 5' -TCAC TGCGAGCCATATGACG- $3^{\prime}$ and $5^{\prime}$-TGCCA CCCAACAAGCCAT-3', and gfp: $5^{\prime}-$ CACATGGTCCTGCTGGAGTTC- $3^{\prime}$ and $5^{\prime}-$ TATCCGCCT CCATCCAGTCTA-3'. Using known quantities of CREB1, CREB2, and cJun mRNAs (range of $0,1,10,100$, and 1000 normalized concentrations) as starting material, the amplification by PCR was in the linear range for all of the bZIP factors with equivalent efficiencies. We therefore normalized expression levels for all the factors to CREB1 (expression level of 1 ) for comparing relative expression of the transcription factors. Expression of cJun was intermediate while expression of CREB2 was the highest. For comparing expression levels between groups over time and treatment, we normalized expression of the transcription factors in each L7 for variations in starting material by comparing expression of GAPDH in each sample.

Quantification and data analysis. All data are expressed as the mean \pm standard error of the mean (SEM) produced by the indicated treatments. The EPSP amplitude was measured in millivolts $(\mathrm{mV})$. The EPSP amplitudes on day 4 were normalized as $100 \%$. The changes in EPSP amplitudes were measured by dividing the EPSP amplitudes on days 5, 7, and 9 by the EPSP amplitude on day 4 multiplied by $100 \%$. No change in amplitude is represented as $100 \%$. Some cultures expressing P-LTF $(27 \%)$ had an increase in synaptic strength that was expressed as an action potential evoked in L7 by the first stimulus to the sensory neuron. A second test was therefore given $20 \mathrm{~s}$ later. This EPSP was assumed to be $40 \%$ lower than the first test, since this is the average decline associated with homosynaptic depression ( $\mathrm{Hu}$ and Schacher, 2014). Thus the strength of the synapse was determined (if an action potential was generated with the first test stimulus) as the amplitude of the second EPSP $\times$ 1.4. All images were viewed with a Nikon Diaphot microscope attached to a silicon-intensified target (Dage 68; Dage-MTI) video camera. Fluorescent intensity (arbitrary units) was measured by the MicrocomputerControlled Imaging Device software package (Imaging Research). ANOVA was used to assess overall significant differences, and the Scheffe $F$ test was used to gauge significant differences between individual treatments. The experiments were not done by blind.

\section{Results}

Expression of cJun and CREB2 in L7 increase with P-LTF

P-LTF lasting more than a week is evoked by $25-\mathrm{HT}$ applications (Hu et al., 2011). A transient form of LTF (lasting only 3 d) that also requires protein and mRNA synthesis (Montarolo et al.,
1986) is evoked by $15-\mathrm{HT}$ applications (Hu et al., 2011). Stimuli that evoke LTF increase CREB1 activation (phosphorylation) and expression and evoke a decrease in CREB2 expression in sensory neurons for up to $2 \mathrm{~d}$ after 5-HT stimuli (Upadhya et al., 2004; Liu et al., 2008, 2011; Rajasethupathy et al., 2012). In addition, levels of activated cJun in sensory neurons are negatively correlated with the formation of stable synapses (Sung et al., 2006). We therefore examined whether changes in the expression of CREB1, CREB2, and cJun in L7 accompany P-LTF. Using qRT-PCR we measured the expression of mRNA for the three transcription factors after treatment with 2 5-HT (Fig. 2).

The level of expression of the three transcription factors in the CNS of Aplysia and in single L7 motor neurons varies significantly. After normalizing for variations in starting material per sample, the ratios of CREB1:cJun:CREB2 mRNA levels were 1:11:118 $(N=4)$ in ganglia of Aplysia, while for motor neuron L7 in culture the ratio of CREB1:CJun:CREB2 was 1:12:101. After normalizing for variations in starting material, the changes in mRNA levels in L7 at $24 \mathrm{~h}$ after 25 -HT $(N=4)$ paralleled the changes observed previously in sensory neurons (Upadhya et al., 2004; Liu et al., 2008, 2011; Rajasethupathy et al., 2012). CREB1 mRNA levels increased, CREB2 mRNA levels decreased, and cJun expression was unchanged in $\mathrm{L} 7$ compared with controls $(N=4)$. These changes in expression produced an overall change in the ratio of mRNA expression to 1:6:30. At $48 \mathrm{~h}$ after $25-\mathrm{HT}(N=4)$, however, the expression of CREB1 mRNA returned to control levels $(N=4)$, while the expression of cJun and CREB2 mRNA levels in L7 increased significantly over the original baseline or control levels (Fig. 2). The ratio of expression was now 1:59: 631. The significant increase in the expression of cJun and CREB2 mRNA suggested that cJun and CREB2 in L7 might contribute to P-LTF. 
A
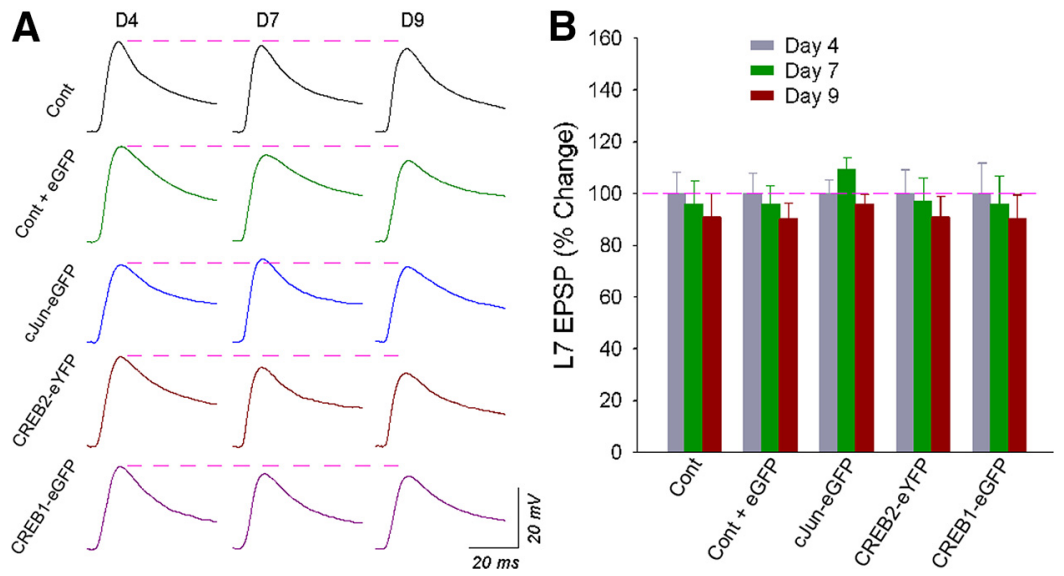

Figure 3. Overexpression of each bZIP factor in L7 fails to significantly alter baseline synapse strength. Constructs were injected into L7 immediately after recording EPSP amplitude on day 4 and synapse amplitudes were re-examined on days 7 and 9. A, Sample traces of EPSPs recorded in L7 before (day 4) and after (days 7 and 9) injection of constructs. Levels of expression and time course for each construct are described in subsequent figures. Note that EPSP amplitudes remain stable over the time period. $\boldsymbol{B}$, Summary of the changes in EPSP amplitudes following no injection (Cont); injection of eGFP construct (Cont + eGFP); or injection of cJun-eGFP, CREB2-eYFP, or CREB1-eGFP constructs. An ANOVA (including the group receiving injection of both constructs; see Fig 4) indicated a significant impact of treatment on EPSP amplitude $\left(F_{(6,76)}=32.34 ; p<0.001\right)$. Individual comparisons indicated that changes in EPSP amplitudes following injection and overexpression of each bZIP factor at each time point was not significantly altered (range in $F$ from 0.059 to $0.356 ; p>0.9$ ) compared with controls or expression of eGFP alone.

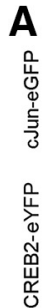
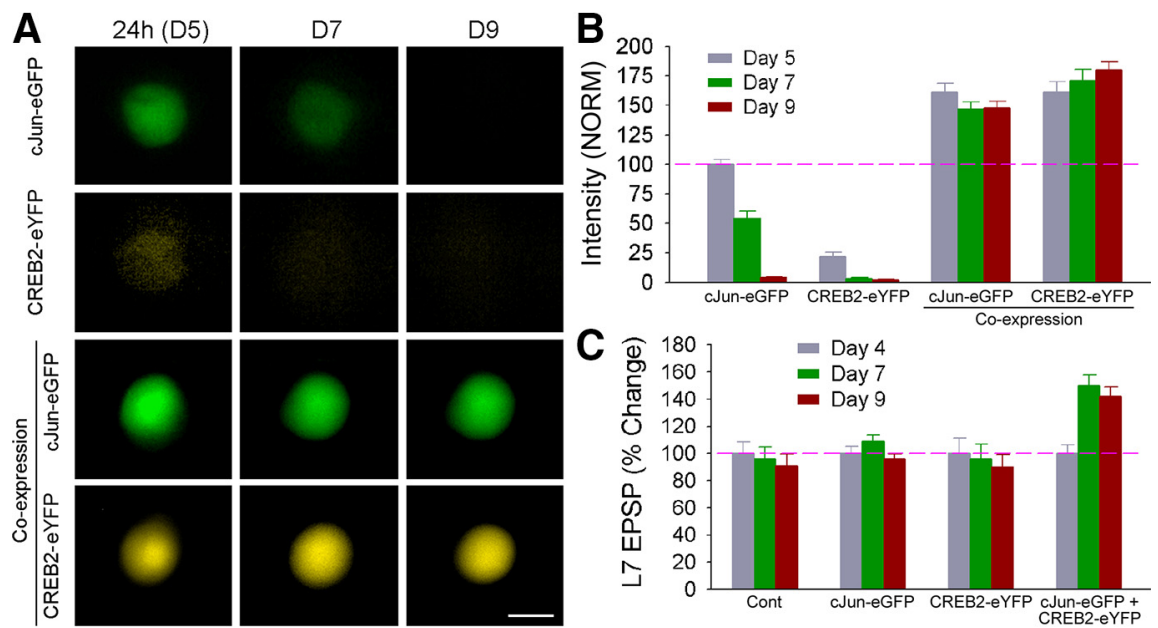

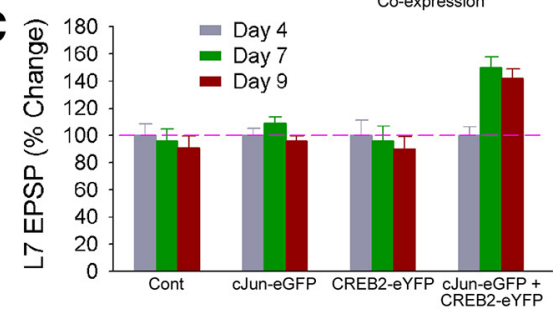

Figure 4. Coexpression of cJun and CREB2 in L7 enhanced expression of the constructs and evoked persistent increase in basal synapse strength. $\boldsymbol{A}, \boldsymbol{B}$, Expression of both cJun and CREB2 are enhanced when both constructs are injected simultaneously into $\mathrm{L} 7$ on day 4. Epifluorescent images of construct expression $(\boldsymbol{A})$ indicate that cJun-eGFP alone is expressed on day 5 (normalized as 100 in $\boldsymbol{B}$ ), while (REB2 is expressed at a significantly lower level (by more than a factor of 4), and is virtually gone by day 7. By day 9 , expression of both clun and CREB2 are at very low levels. In contrast, when the constructs were coinjected, expression of each construct is enhanced significantly (lower portion of $\boldsymbol{A}$ ) and high levels of expression are maintained over time. Scale bar, $100 \mu \mathrm{m}$. A summary of construct expression levels (normalized) over time is depicted in $\boldsymbol{B}$. A two-factor ANOVA (treatment and time) indicated a significant difference between the groups $\left(F_{(6,76)}=86.01 ; p<0.001\right)$. Individual comparisons indicated that when each bzIP factor was injected alone, intensity of clun expression was greater than CREB2 on days $5(F=13.78 ; p<0.01)$ and $7(F=5.928 ; p<0.01)$, but not on day $9(F=0.015 ; p>0.9)$. Expression of the constructs at each time point was significantly higher when injected simultaneously than the expression of the construct when injected alone (for clun the range was $F=10.413-110.587 ; p<0.01$, and for CREB2 the range was $F=53.951-168.746 ; p<0.01$ ). C, Summary of the changes in synapse strength in controls, injection of each construct alone (see Fig. 3), and after coinjection of both constructs. A two-factor ANOVA (includes all experimental groups described in Figs. 3 and 4) indicated a significant change in EPSPs $\left(F_{(6,76)}=32.34 ; p<0.001\right)$. Individual comparisons indicated that coexpression increased EPSP amplitude at each time point (days 7 and 9$)$ compared with control $(F=7.997 ; p<0.01$ and $F=8.485 ; p<0.01)$, expression of clun alone $(F=4.53$; $p<0.01$ and $F=6.922 ; p<0.01)$, or expression of CREB2 alone $(F=7.599 ; p<0.01$ and $F=8.444 ; p<0.01)$. Injection of each construct alone failed to increase EPSP amplitude compared with controls (range of $F$ from 0.0004 to $0.395 ; p>0.9$; see also Fig. 3).

Overexpressing both cJun and CREB 2 in L7 or sensory neuron evoke a persistent change in basal synapse strength We next examined the consequences on synaptic strength evoked by overexpression of CREB1-eGFP, CREB2-eYFP, or cJun-eGFP constructs in L7 (Figs. 3, 4). Overexpression of each fluorescent-tagged transcription factor after injecting individual constructs into the nuclei of L7 on day 4 (sensorimotor synapses achieve a stable baseline) resulted in no significant change in EPSP amplitudes on days 7 and 9 compared with their original baseline on day 4 or to the change in synapse strength after injection of a control construct (eGFP alone) into L7 (Figs. 3, 4). Expression of the constructs following injection differed significantly. In L7, CREB1 and cJun expression was detected on day 5 and persisted to day 7. Unlike cJun or CREB2, low levels of fluorescence for CREB1 were also detected in the main axon of L7 (Fig. 8A). In contrast, CREB2 expression was weak on day 5 and did not materialize by day 7 in L7 (Fig. 4A,B). This lack of expression was not due to failure to synthesize the construct mRNA. Using qRT-PCR to monitor the expression of the fluorescent protein portion of the mRNAs indicated no significant difference in the transcription of each construct in L7 ( $N=4$ each; data not shown). Overexpression of cJun $(N=8)$ or CREB1 $(N=7)$ alone failed to significantly affect synapse strength on day $7(109 \pm 4.6 \%$ or $96 \pm 10.7 \%)$ and day $9(96 \pm 3.6 \%$ or $90 \pm 9.4 \%)$ compared with the synapse strength in controls $(N=8 ; 96 \pm 8.8 \%$ on day 7 and $91 \pm$ $8.9 \%$ on day 9$)$. Overexpression of CREB2 alone $(N=8)$ also failed to alter synapse strength on days $7(97 \pm 9.0 \%)$ and 9 (91 $\pm 8.0 \%)$, while attempts to overexpress CREB2 were stymied at the protein level despite transcription of the mRNA encoding the construct (Figs. 3, 4). This suggests that regulation of translation and/or degradation impacts the expression of CREB2 protein in L7.

Since both CREB 2 and cJun expression increased following $25-\mathrm{HT}$, we examined whether overexpression of both constructs (cJun-eGFP and CREB2-eYFP) would increase basal synapse strength (Fig. 4). Coinjection of both constructs into L7 resulted in both an enhancement and persistent expression of CREB2 and cJun in L7, and a significant increase in the strength of the sensorimotor synapses of $150 \pm 8.1 \%(N=13)$ on day 7 compared with expression of each construct alone (109 $\pm 4.6 \%$ for cJun or $97 \pm 9.0 \%$ for CREB2; Figs. 3, 4). This increase in synapse strength persisted to day 9 , where coexpression of cJun and CREB2 resulted in a significant increase of synapse strength to $142 \pm 7.3 \%$ compared with the changes evoked by overexpressing each construct alone (96 $\pm 3.6 \%$ in cJun or $91 \pm 8.0 \%$ in CREB2; Figs. 3, 4). With coexpression, CREB2 construct was readily detected on day 
5 and persisted to day 9. Expression of cJun also persisted to day 9 (Fig. $4 A, B$ ). Thus it appears that the expression of CREB2 protein is enhanced when cJun is overexpressed. Overexpression of cJun and CREB2 in L7 without 5-HT application can lead to a persistent increase in synapse strength that parallels the change evoked by 25 -HT.

In contrast, coexpressing cJun and CREB2 in sensory neurons evoked the opposite change in synapse strength-a significant and persistent decrease in the strength of sensorimotor synapses (Fig. 5). In sensory neurons, both cJun and CREB2 were expressed at relatively strong levels on day 5 that persisted to day 9. The levels of expression (fluorescent intensity) of cJun and CREB2 when coexpressed in sensory neurons were not significantly different from expression for each construct alone (Fig. 5A,B). With coexpression in the sensory neuron, synapse strength declined to $48 \pm 10.8 \%$ on day 7 and $44 \pm 12.6 \%$ on day $9(N=9$; Fig. $5 C)$. This decline in synapse strength was significant compared with the changes of $97 \pm 8.7$ and $91 \pm 7.9 \%$ for controls $(N=9), 103 \pm 11.2$ and $95 \pm$ $10.3 \%$ for overexpressing cJun alone in the sensory neurons $(N=10)$, or $96 \pm$ 9.2 and $92 \pm 7.6 \%$ for overexpressing CREB2 alone in the sensory neurons $(N=11)$. Thus, there appears to be cellspecific regulation in the expression of CREB2 in presynaptic and postsynaptic components of a stable synapse. Moreover, bidirectional changes in basal synapse strength are evoked with cell-specific changes in the coexpression of the same bZIP transcription factors.

\section{Increase in cJun and CREB2 in L7 contributes to P-LTF}

Since overexpression of each construct alone failed to alter synapse strength, we next examined whether overexpression of each construct in L7 can replace the second day of 5-HT applications to produce P-LTF. On day 5, instead of the second set of 5-HT applications, construct for cJun-eGFP (Fig. 6), CREB2-eYFP (Fig. 7), or CREB1-eGFP (Fig. 8) was injected into L7. Synapse strength was monitored on days 7 and 9.

Overexpression of wild-type cJun-eGFP in L7 after 1 5-HT, but not a mutant dominant-negative form that cannot be phosphorylated by JNK (Ser54, which is homologous to Ser73 of mammalian cJun, was changed to alanine; Sung et al., 2006), produced P-LTF. The EPSP amplitudes increased significantly to $150 \pm$ $6.8 \%$ on day 7 and $140 \pm 7.0 \%$ on day 9 (15-HT + cJun-eGFP; $N=25)$ and were comparable to the increases evoked by $25-\mathrm{HT}$ $(163 \pm 11.3 \%$ on day 7 and $154 \pm 9.8 \%$ on day $9 ; N=8)$, and was significantly greater than the changes in EPSP amplitudes on days 7 and 9 evoked when L7 was injected with the mutant form of cJun (1 5-HT + cJun-dn-eGFP; $119 \pm 9.7$ and $95 \pm 8.3 \%$; $N=$ 12), 15 -HT alone $(120 \pm 10.4$ and $90 \pm 7.8 \%$; $N=14)$, Cont + eGFP ( $97 \pm 8.5$ and $89 \pm 7.4 \% ; N=14$ ), or Cont + cJun-eGFP $(109 \pm 9.9$ and $96 \pm 9.3 \% ; N=10$; Fig. $6 C)$. Expression of all constructs persisted to day 7 (Fig. $6 A, B$ ).
Overexpression of CREB2-eYFP in L7 after 15 -HT produced P-LTF and the persistent expression of the CREB2 construct (Fig. 7). The EPSP amplitudes on days 7 and 9 increased significantly after L7 was injected with CREB2-eYFP on day 5 (1 5-HT + CREB2-eYFP; $151 \pm 13.2$ and $141 \pm 12.1 \% ; N=12)$ and was comparable to the increases evoked by $25-\mathrm{HT}(163 \pm 11.3$ and $154 \pm 9.8 \% ; N=8$ ). The change in EPSP amplitudes was also significantly greater than the changes in EPSP amplitudes evoked on days 7 and 9 when L7 was injected with control constructs on day 5: $114 \pm 7.5$ and $91 \pm 5.9 \%$ for $15-\mathrm{HT}+\operatorname{eYFP}(N=8)$ or $96 \pm 11.0$ and $90 \pm 11.2 \%$ for Cont + CREB2-eYFP $(N=10$; Fig. $7 C)$. Unlike the situation where the CREB2 construct was injected alone, construct injected $24 \mathrm{~h}$ after 15 -HT was expressed in the nucleus of L7 at significantly high levels that persisted to day 7 (Fig. $7 A, B$ ). Thus, the expression of CREB2 protein in L7 is facilitated by treatment with 5-HT as well as cJun expression (Fig. 4). The enhanced expression of CREB2 together with cJun contributes to a persistent increase in synapse strength (P-LTF).

Does overexpression of any bZIP transcription factor in L7 after 1 5-HT lead to P-LTF? Overexpression of CREB1-eGFP in L7 after 15 -HT treatment failed to produce P-LTF (Fig. 8). After injection of CREB1-eGFP into L7 on day 5 (1 5-HT + CREB1eGFP; $N=10)$, the EPSP amplitudes on days 7 and $9(115 \pm 8.1$ and $95 \pm 7.1 \%)$ were not significantly different from EPSPs recorded after $15-\mathrm{HT}$ alone $(120 \pm 11.6$ and $97 \pm 10.0 \% ; N=7)$ or 15 -HT + eGFP $(121 \pm 11.6$ and $98 \pm 9.7 \% ; N=8)$ or Cont + eGFP ( $93 \pm 8.6$ and $90 \pm 8.5 \% ; N=8)$ and were significantly lower than the EPSPs recorded after 2 5-HT $(163 \pm 11.3$ and $154 \pm 9.8 \% ; N=8$ ). Expression of the construct persisted to day 

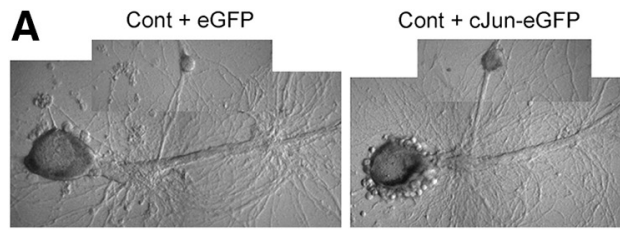

$15-\mathrm{HT}+$ cJun-eGFP
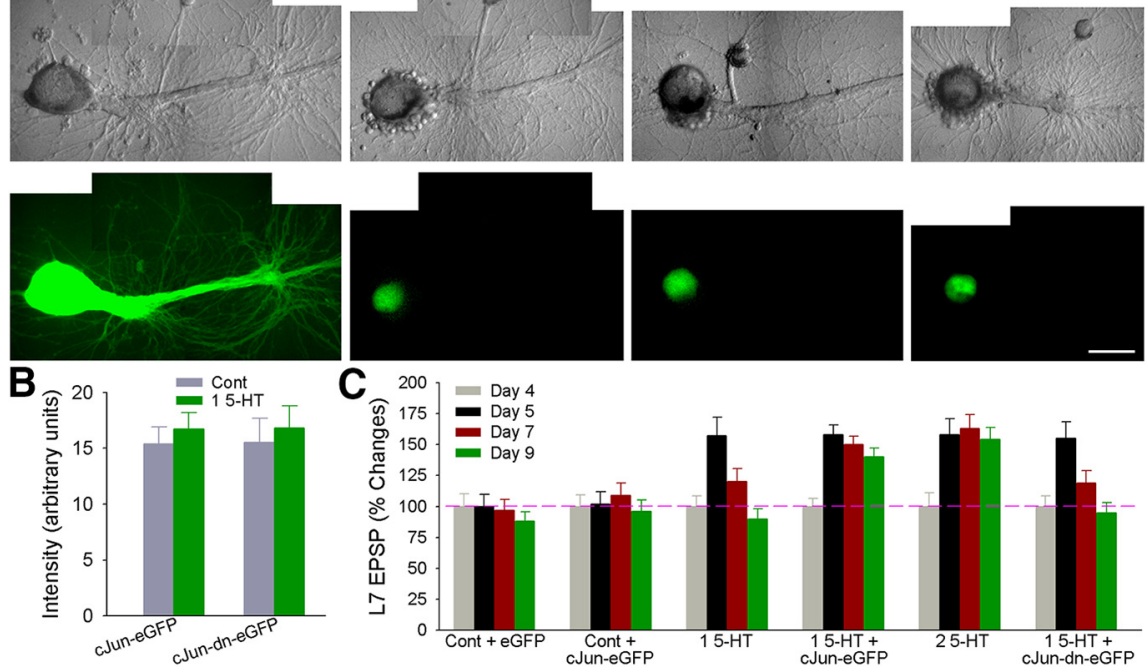

Figure 6. P-LTF is evoked when wild-type cJun is overexpressed in L7 as a substitute for the second set of 5-HT applications. $\boldsymbol{A}$, Constructs are expressed on day 7, $48 \mathrm{~h}$ after construct injection on day 5. Constructs were injected $24 \mathrm{~h}$ after control or 15-HT treatment on day 4. Nomarski contrast and epifluorescent images showing expression of the constructs in the same view areas indicate that wild-type cJun and a dominant-negative form of cJun are expressed in the nuclei of $L$ 7. Peak expression of each construct is on day 7 and declines by day 9 . Scale bar, $100 \mu \mathrm{m}$. B, Summary of the intensity of the fluorescent signal detected in the nuclei of $\mathrm{L} 7$ after control or 15-HT treatment. An ANOVA indicated that intensity of the signal for both the wild-type and dominantnegative mutant form of Jun was not altered significantly by treatment with 15-HT $\left(F_{(2,38)}=0.298 ; p>0.5\right)$. C, Summary of the changes in EPSP amplitude indicates that overexpression of wild-type clun on day 5 after $15-\mathrm{HT}$, but not the dominant-negative form of clun, evoked a P-LTF that is indistinguishable from that evoked by $25-\mathrm{HT}$. An ANOVA indicated a significant change with treatment $\left(F_{(15,231)}=18.676 ; p<0.001\right)$. Individual comparisons indicated that overexpression of wild-type clun after 15-HT (1 $5-\mathrm{HT}+$ (Jun-eGFP) significantly increased EPSP amplitudes on days 7 and 9 that were not different from the increases evoked by $25-\mathrm{HT}(F=0.18 ; p>0.6$ and $F=0.268 ; p>0.8)$. On day 7 overexpression of wild-type clun after 15 -HT significantly increased EPSP amplitude compared with Cont + eGFP and Cont + cJun-eGFP $(F=4.404 ; p<0.01$ and $F=2.12 ; p<0.05)$, while overexpression of the mutant form of cJun after $15-\mathrm{HT}(15-\mathrm{HT}+\mathrm{dn}$-cJun-eGFP) failed to significantly change EPSP amplitudes compared with the controls $(F=0.53 ; p>0.08$ and $F=0.093 ; p>0.9$, respectively). On day 9 overexpression of wild-type clun after 15-HT resulted in EPSP amplitudes that remained significantly higher compared with Cont $+\mathrm{eGPF}(F=5.018 ; p<0.01)$, Cont + cun-eGFP $(F=2.89 ; p<0.03), 15$-HT alone $(F=4.354 ; p<0.01)$ m or 15 -HT + dn-cJun-eGPF $(F=3.386 ; p<0.01)$. Injection of the mutant form of cJun after 15-HT failed to change EPSP amplitude compared with all controls.

7, and was unaffected by treatment (Fig. $8 A, B$ ). Thus, overexpressing CREB1 in L7 does not substitute for a second set of 5-HT applications in producing P-LTF.

Since overexpression of wild-type cJun in $\mathrm{L} 7$ can replace the second set of 5-HT applications to produce persistent increases in synapse strength, we next examined whether overexpression of the nonphosphorylatable dominant-negative form of cJun (cJun-dn-eGFP) in L7 after 25 -HT would interfere with the expression of P-LTF. cJun-dn-eGFP or control constructs were injected into L7 after the second set of 5-HT applications.

Overexpression of the dominant-negative form of cJun (injection of cJun-dn-eGFP into L7 $6 \mathrm{~h}$ after the second set of 5-HT applications) blocked P-LTF (Fig. 9). Whereas 25 -HT or 25 -HT + eGFP evoked significant increases in EPSP amplitudes on days 7 and $9(168 \pm 16.7$ and $155 \pm 13.3 \% ; N=7 ; 169 \pm 14.9$ and $158 \pm 14.8 \% ; N=10)$, injection of the dominant-negative cJun (2 5-HT + cJun-dn-eGFP; $N=13$ ) resulted in significantly smaller EPSP amplitudes on days 7 and $9(125 \pm 11.0$ and $105 \pm$ $8.3 \%)$. After injection of the dominant-negative cJun, EPSP amplitudes were not significantly different from the changes evoked on days 7 and 9 after 15 -HT (122 \pm 11.8 and $97 \pm 9.3 \% ; N=7)$ and were not significantly different from untreated controls on days 7 and $9(95 \pm 6.8$ and $91 \pm 7.0 \% ; N=10)$. Overexpression of the dominant-negative cJun alone (Cont + cJun-dn-eGFP; $N=7$ ) failed to alter basal synapse strength. Changes in EPSP on
$15-\mathrm{HT}+$ cJun-dn-eGFP
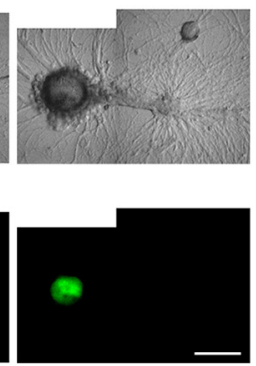

days 7 and $9(96 \pm 8.7$ and $91 \pm 9.2 \%)$ were not significantly different from untreated controls. Together with the results described in Figure 6, increased cJun expression/activity is required for P-LTF.

\section{Discussion}

Stimuli that evoked P-LTF of sensorimotor synapses in Aplysia produced increases in the expression of both cJun and CREB2 mRNA in L7, and increased expression of both cJun and CREB2 in L7 evoked persistent increases in synapse strength. The time course for the changes in expression suggests a cascade of cellular responses evoked directly by 5-HT (Cleary et al., 1998; Li et al., 2005; Villareal et al., 2007; Fulton et al., 2008) and/or by orthograde signaling from the sensory neuron to the postsynaptic target (Zhu et al., 1997; Schacher et al., 2000). Thus, the upregulation of CREB2 and cJun in L7, combined with the increase in CREB1 and decrease in CREB2 in sensory neurons (Upadhya et al., 2004; Liu et al., 2008, 2011; Rajasethupathy et al., 2012), orchestrate alterations in the expression of effector gene products in both the postsynaptic and presynaptic neurons to regulate persistent changes in the strength of the sensorimotor synapse.

\section{High levels of CREB2 and cJun in postsynaptic neuron $\mathrm{L} 7$ regulate synapse strength}

CREB2 mRNA expression in freshly dissected CNS of Aplysia or individual L7 motor neurons was significantly greater than CREB1 and cJun mRNAs. At the protein level, however, the difference in expression is less dramatic. Levels of CREB1 and CREB2 protein in molluscan neurons are much closer to each other than would be predicted by the large differences in their mRNA levels (Wagatsuma et al., 2005; Fioravante et al., 2008; Liu et al., 2011; Rajasethupathy et al., 2012). Thus, post-transcriptional mechanisms, either translation repression or increased protein degradation (Fuchs and Ronai, 1999; Lassot et al., 2001; Ameri and Harris, 2008; Fiovarante et al., 2008; Rajasethupathy et al., 2012), or transport of CREB2 protein to distal sites (Lai et al., 2008), regulate the level of CREB2 protein in neuronal nuclei (Bartsch et al., 1995; Hai and Hartman, 2001; Mohamed et al., 2005). CREB2 protein level in L7 appears to be more tightly regulated than in sensory neurons by post-transcriptional modulation, since there is little expression of CREB2 protein after CREB2 construct alone is injected in L7 despite a high level of expression of the mRNA encoding the CREB2 construct. In addition, CREB2 expression in L7 appears to be regulated by protein degradation, since construct expression is enhanced after injection in L7 when the cultures were incubated with a permeable inhibitor of the ubiquitin proteasome pathway (MG132; Chain et al., 1999; data not shown).

As observed with sensory neurons (Liu et al., 2008, 2011; Rajasethupathy et al., 2012), the initial response in L7 to stimuli that produce P-LTF was a small increase in CREB1 mRNA and a small decrease in CREB2 mRNA. These changes may reflect the release of the brake on synapse strength and the induction of P-LTF 
evoked by 5-HT (Bartsch et al., 1995). By $48 \mathrm{~h}$, however, expression of both CREB2 and cJun mRNAs was significantly higher than prestimulus or control levels, while CREB1 mRNA returned to control levels. Both CREB2 and cJun are activators of transcription as either homodimers or as heterodimers formed with each other or with other transcription factors. Since each transcription factor complex binds to different oligonucleotide sequences (Benbrook and Jones, 1994; Chinenov and Kerppola, 2001; Hai and Hartman, 2001; Ameri and Harris, 2008; Raivich, 2008), the increase in their expression and potential interactions with other factors may serve to orchestrate new gene expression required to maintain the increase in synapse strength.

The basal strength of sensorimotor synapses increased significantly when CREB2 and cJun expressions were elevated simultaneously in L7 and decreased significantly when the same transcription factors were elevated simultaneously in sensory neurons. From a functional standpoint, the increase in synapse strength evoked by the simultaneous increase in CREB2 and cJun expression in L7 matched the persistent changes in the strength of sensorimotor synapses evoked by 25 -HT. Although we do not know whether any presynaptic changes accompany this increase in synapse strength produced by manipulating simultaneous expression of bZIP factors in L7, retrograde signals induced in L7 can evoke changes that affect presynaptic function and structure (Glanzman et al., 1989, 1990; Sun and Schacher, 1996; Sun et al., 1996; Schacher et al., 1999; Hu et al., 2002, 2004, 2010; Cai et al., 2008). Both presynaptic and postsynaptic changes (Schacher and Montarolo, 1991; Wu and Schacher, 1994) may also contribute to persistent synaptic depression evoked with simultaneous elevation of both CREB2 and cJun in sensory neurons. Thus, cell-specific alterations in bZIP factor expression/ activity may not be cell autonomous; expression of downstream effector gene products in a target neuron could affect the molecular and structural properties in other interacting neurons in the circuit. Moreover, changes in expression/activity of bZIP factors in a neuron in certain situations may have similar (Du et al., 2009) or different consequences on its presynaptic and postsynaptic functions - an increase in its inputs and a decrease in its outputs - thereby affecting overall synapse homeostasis of neural circuits.

The expression of CREB2 protein in L7 was altered by changes in the expression of other transcription factors (cJun) and as a downstream consequence of 5-HT stimulation. In the presence of increased cJun expression, CREB2 protein expression was much stronger and persisted. This raises the possibility that CREB2 protein expression is modulated by cJun regulating the expression or stability of CREB2 mRNA, by cJun regulating the expression of molecules that protect CREB2 protein from degradation, or by cJun heterodimerizing with CREB2 protein thereby protecting CREB2 protein from degradation (Fuchs and Ronai, 1999; Lassot et al., 2001; Ameri and Harris, 2008; Raivich, 2008). Direct measurement with specific antibodies of different forms of cJun and CREB2 proteins and their potential interactions following 25 -HT would address these possibilities. The changes in bZIP factor expression could alter the properties of L7 directly by inducing persistent changes in the expression of key molecules that impact the expression and distribution of postsynaptic receptors (Zhu et al., 1997; Li et al., 2005; Villareal et al., 2007; Hu et al., 2008) or by regulating potential retrograde signals that affect the properties of the presynaptic sensory neuron to induce a persistent change in synapse strength (Glanzman et al., 1990; Hu et al., 2002, 2004, 2010; Cai et al., 2008). In future studies we will determine whether CREB2-cJun heterodimers are formed under these conditions and protect CREB2 from degradation and the identity of some of the effector genes regulated in L7 by cJun, CREB2, and the heterodimers they may form that may contribute to the change in synapse strength. In addition we will explore how each manipulation in L7 that evokes an increase in synapse strength affects the cellular and molecular properties of both the presynaptic sensory neuron and L7 that are consistent with 
A Cont + eGFP
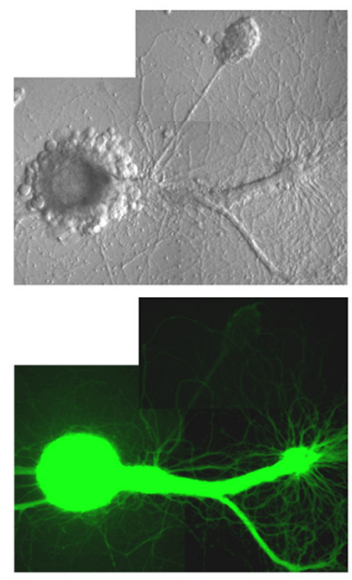

B

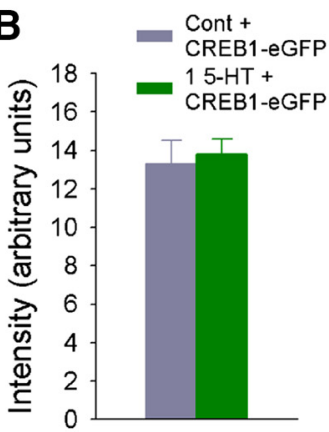

Cont + CREB1-eGFP
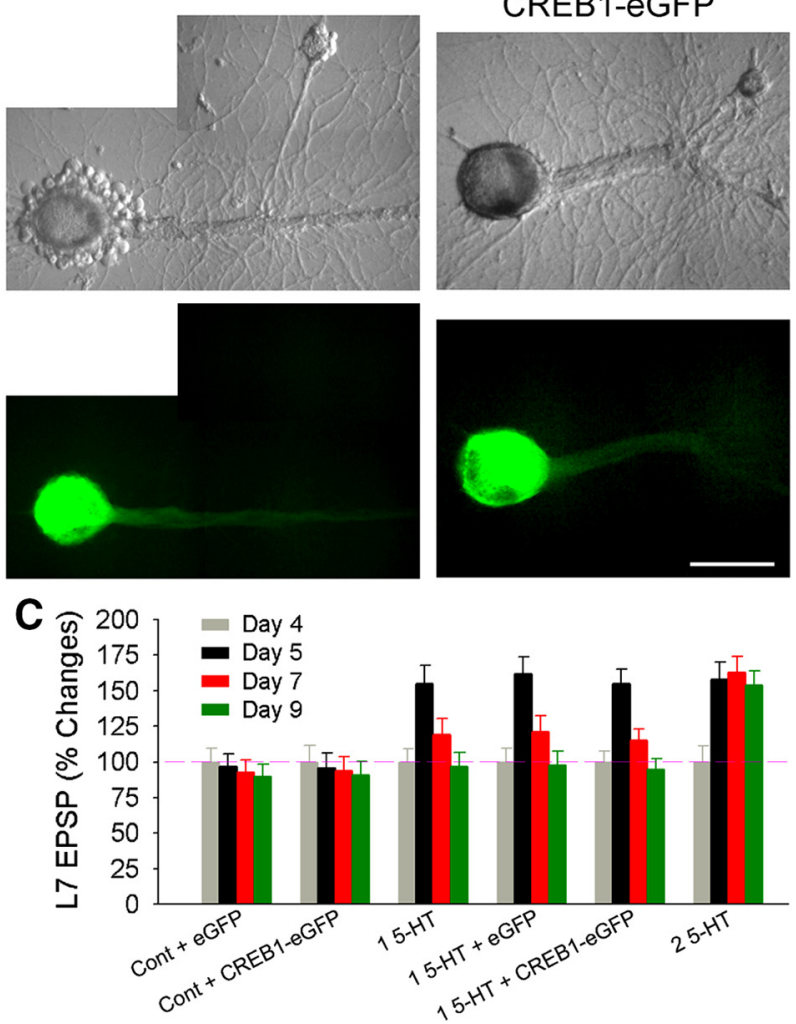

Figure 8. P-LTF is not evoked when CREB1 is overexpressed in $\mathrm{L} 7$ as a substitute for the second set of 5-HT applications. $\boldsymbol{A}$, Constructs are expressed on day 7, $48 \mathrm{~h}$ after construct injection on day 5 . Constructs were injected $24 \mathrm{~h}$ after control (Cont + eGFP or Cont + (REB1-eGFP) or 15-HT treatment (15-HT + eGFP or 15-HT + (REB1-eGFP). Nomarski contrast and epifluorescent images showing expression of the constructs in the same view areas after control or 15-HT treatments show that CREB1 is expressed at relatively high levels in the nuclei of $\mathrm{L} 7$. Note that weak fluorescent signal extends into the main axon of $\mathrm{L} 7$. Scale bar, $100 \mu \mathrm{m}$. B, Summary of the intensity of the fluorescent signal detected in the nuclei of $\mathrm{L7}$ after control or 15-HT treatment. An ANOVA indicated that intensity of the signal for CREB1 expression after 15 -HT was not significantly different from expression after control treatment $\left(F_{(1,15)}=0.111 ; p>0.7\right)$. C, Summary of the changes in EPSP amplitude indicates that overexpression of CREB1 on day 5 after 15 -HT fails to evoke P-LTF and evokes changes that parallel 15-HT treatment. A two-factor ANOVA indicated a significant change with treatment $\left(F_{(15,123)}=30.582 ; p<0.001\right)$. Individual comparisons indicated that overexpression of CREB1 after 1 5 -HT (15-HT + CREB1-eGFP) failed to evoke a significant change in EPSP on days 7 and 9 compared with Cont + eGFP $(F=0.522 ; p>$ 0.8 and $F=0.038 ; p>0.9), 15-H T+\operatorname{eGFP}(F=0.042 ; p>0.9$ and $F=0.011 ; p>0.9)$, and 15 -HT alone $(F=0.025 ; p>0.9$ and $F=$ $0.004 ; p>0.9$ ). In contrast, $25-\mathrm{HT}$ evoked significant increases in ESPSP amplitude compared with all other groups on day 7 (range of $F=$ 2.554 to $F=4.847 ; p<0.05$ to $<0.01$ ) and on day 9 (range of $F=3.83$ to $F=5.173 ; p<0.01$ ).

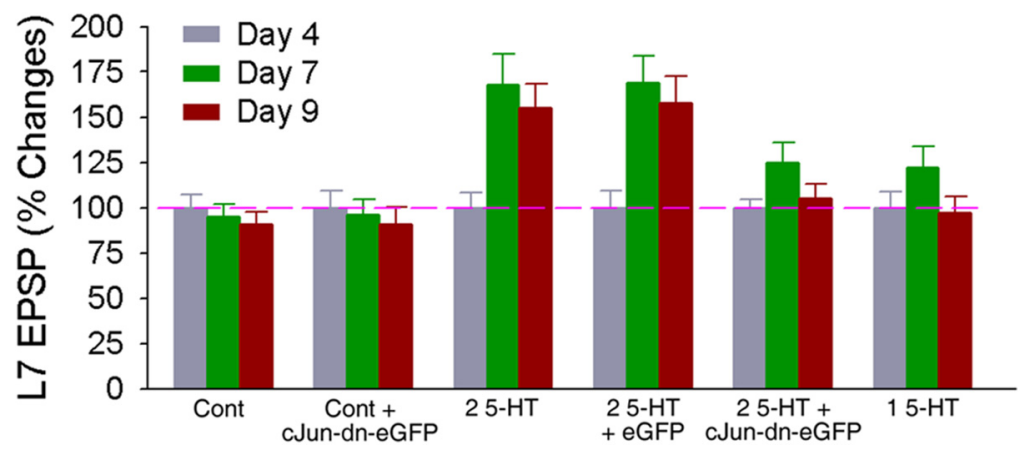

Figure 9. P-LTF is blocked following overexpression of a dominant-negative form of clun after the second set of 5-HT applications. Summary of the changes in EPSP amplitude indicates that overexpression of clun-dn-eGFP beginning on day 5 after 25-HT blocks P-LTF. A two-factor ANOVA indicated a significant change $\left(F_{(10,94)}=14.616 ; p<0.001\right)$. Individual comparisons indicated that overexpression of cJun-dn-eGFP after 25-HT (25-HT + clun-dn-eGFP) failed to evoke a significant increase in EPSP amplitude on days 7 and 9 compared with Cont $(F=0.790 ; p>0.8$ and $F=0.243 ; p>0.9)$, and it is not different from that of $15-\mathrm{HT}(F=0.007$; $p>0.9$ and $F=0.060 ; p>0.9)$. In contrast, $25-\mathrm{HT}$ or $25-\mathrm{HT}+$ eGFP evoked significant increases in ESPSP amplitude compared with2 5 -HT + cun-dn eGFP on days $7(F=2.495 ; p<0.05$ or $F=2.959 ; p<0.05)$ and $9(F=2.591 ; p<0.05$ or $F=3.579 ; p<0.01)$ and to Cont on day $7(F=3.308 ; p<0.01$ or $F=4.144 ; p<0.01)$ and on day $9(F=3.352 ; p<0.01$ or $F=4.419 ; p<0.01)$. changes in synapse strength- increase/decrease in presynaptic varicosities (Glanzman et al., 1990; Bailey et al., 1992) and increase/decrease in the surface expression and function of glutamate receptors (Zhu et al., 1997; Li et al., 2005).

\section{CREB2 and cJun in postsynaptic}

neuron L7 contribute to P-LTF evoked by $5-\mathrm{HT}$

Increasing either CREB2 or cJun mRNA in L7 did not affect synapse baseline, but increasing either transcription factor, but not CREB1, converted a transient form of LTF produced by 15 -HT to a persistent form of LTF that is normally produced by 2 5-HT. Moreover, expression of CREB2eGFP protein in L7 was significantly higher after $15-\mathrm{HT}$ treatment compared with controls. The combined impact of higher CREB2 mRNA plus the apparent decline in CREB2 protein degradation evoked by 5 -HT applications might lead to higher levels of CREB2 protein. In L7, increased CREB2 could combine with higher levels of cJun, which even in the absence of 5-HT evoked P-LTF. Increase in wild-type cJun expression, but not a mutant form of cJun, after 15 -HT also evoked P-LTF. The increase in cJun activity is critical for P-LTF, since overexpression of the mutant form of cJun after 2 5-HT blocks P-LTF. Thus the increase in cJun, combined with the actions of 5-HT in increasing CREB2 protein expression in L7 would contribute to the expression of P-LTF.

Our data are consistent with the idea that P-LTF evoked by 25 -HT requires changes in L7 that include an increase in the expression/activity of CREB2 and cJun. The first day of 5-HT applications leads to an increase of CREB2 protein expression in L7, most likely as a result of reducing CREB2 degradation. The second day of 5-HT applications evokes changes that lead to the elevation of both CREB2 and cJun mRNA expression. The combination of a reduction in CREB2 protein degradation and increase in expression of CREB2 and cJun could lead to an increase CREB2-, cJun-, and CREB2-cJun-dependent regulation of gene expression in L7 required for maintaining persistent increases in synapse strength. In future studies we will examine how each change evoked in L7 by $25-\mathrm{HT}$ affects expression of downstream effector genes that contribute to persistent longterm plasticity.

\section{References}

Alberini CM (2009) Transcription factors in long-term memory and synaptic plasticity. Physiol Rev 89:121-145. CrossRef Medline 
Alberini CM, Chen DY (2012) Memory enhancement: consolidation, reconsolidation and insulin-like growth factor 2. Trends Neurosci 35:274283. CrossRef Medline

Alberini CM, Ghirardi M, Metz R, Kandel ER (1994) C/EBP is an immediate-early gene required for the consolidation of long-term facilitation in Aplysia. Cell 76:1099-1114. CrossRef Medline

Ameri K, Harris AL (2008) Activating transcription factor 4. Int J Biochem Cell Biol 40:14-21. CrossRef Medline

Bailey CH, Montarolo P, Chen M, Kandel ER, Schacher S (1992) Inhibitors of protein and RNA synthesis block structural changes that accompany long-term heterosynaptic plasticity in Aplysia. Neuron 9:749-758. CrossRef Medline

Bartsch D, Ghirardi M, Skehel PA, Karl KA, Herder SP, Chen M, Bailey CH, Kandel ER (1995) Aplysia CREB2 represses long-term facilitation: relief of repression converts transient facilitation into long-term functional and structural change. Cell 83:979-992. CrossRef Medline

Bartsch D, Casadio A, Karl KA, Serodio P, Kandel ER (1998) CREB1 encodes a nuclear activation, a repressor and a cytoplasmic modulator that form a regulatory unit critical for long-term facilitation. Cell 95:211-223. CrossRef Medline

Bartsch D, Ghirardi M, Casadio A, Giustetto M, Karl KA, Zhu H, Kandel ER (2000) Enhancement of memory-related long-term facilitation by ApAF, a novel transcription factor that acts downstream from both CREB1 and CREB2. Cell 103:595-608. CrossRef Medline

Benbrook DM, Jones NC (1994) Different binding specificities and transactivation of variant CRE's by CREB complexes. Nucleic Acids Res 22:14631469. CrossRef Medline

Cai D, Chen S, Glanzman DL (2008) Postsynaptic regulation of long-term facilitation in Aplysia. Curr Biol 18:920-925. CrossRef Medline

Carlezon WA, Duman RS, Nestler EJ (2005) The many faces of CREB. Trends Neurosci 28:436-445. CrossRef Medline

Chain DG, Casadio A, Schacher S, Hegde AN, Valbrun M, Yamamoto N, Goldberg AL, Bartsch D, Kandel ER, Schwartz JH (1999) Mechanisms for generating the autonomous cAMP-dependent protein kinase required for long-term facilitation in Aplysia. Neuron 22:147-156. CrossRef Medline

Chen A, Muzzio IA, Malleret G, Bartsch D, Verbitsky M, Pavlidis P, Yonan AL, Vronskaya S, Grody MB, Cepeda I, Gilliam TC, Kandel ER (2003) Inducible enhancement of memory storage and synaptic plasticity in transgenic mice expressing an inhibitor of ATF4 (CREB-2) and C/EBP proteins. Neuron 39:655-669. CrossRef Medline

Chinenov Y, Kerppola TK (2001) Close encounters of many kinds: fos-jun interactions that mediate transcription regulatory specificity. Oncogene 20:2438-2452. CrossRef Medline

Cleary LJ, Lee WL, Byrne JH (1998) Cellular correlates of long-term sensitization in Aplysia. J Neurosci 18:5988-5998. Medline

Dash PK, Hochner B, Kandel ER (1990) Injection of the cAMP-responsive element into the nucleus of Aplysia sensory neurons blocks long-term facilitation. Nature 345:718-721. CrossRef Medline

Davis S, Vanhoutte P, Pages C, Caboche J, Laroche S (2000) The MAPK/ ERK cascade targets both Elk-1 and cAMP response element-binding protein to control long-term potentiation-dependent gene expression in the dentate gyrus in vivo. J Neurosci 20:4563-4572. Medline

Deisseroth K, Bito H, Tsien RW (1996) Signaling from synapse to nucleus: postsynaptic CREB phosphorylation during multiple forms of hippocampal synaptic plasticity. Neuron 16:89-101. CrossRef Medline

Du JL, Wei HP, Wang ZR, Wong ST, Poo MM (2009) Long-range retrograde spread of LTP and LTD from optic tectum to retina. Proc Natl Acad Sci U S A 106:18890-18896. CrossRef Medline

Fioravante D, Liu RY, Byrne JH (2008) The ubiquitin-proteasome system is necessary for long-term synaptic depression in Aplysia. J Neurosci 28: 10245-10256. CrossRef Medline

Fuchs SY, Ronai Z (1999) Ubiquitination and degradation of ATF2 are dimerization dependent. Mol Cell Biol 19:3289-3298. Medline

Fulton D, Condro MC, Pearce K, Glanzman DL (2008) The potential role of postsynaptic phospholipase $\mathrm{C}$ activity in synaptic facilitation and behavioral sensitization in Aplysia. J Neurophysiol 100:108-116. CrossRef Medline

Glanzman DL, Kandel ER, Schacher S (1989) Identified target motor neuron regulates neurite outgrowth and synapse formation of Aplysia sensory neurons in vitro. Neuron 3:441-450. CrossRef Medline

Glanzman DL, Kandel ER, Schacher S (1990) Target-dependent structural changes accompanying long-term synaptic facilitation in Aplysia neurons. Science 249:799-802. CrossRef Medline

Glyvuk N, Tsytsyura Y, Geumann C, D’Hooge R, Hüve J, Kratzke M, Baltes J, Böning D, Klingauf J, Schu P (2010) AP-1/sigmalB-adaptin mediates endosomal synaptic vesicle recycling, learning and memory. EMBO J 29: 1318-1330. CrossRef Medline

Gruart A, Benito E, Delgado-García JM, Barco A (2012) Enhanced cAMP response element-binding protein activity increases neuronal excitability, hippocampal long-term potentiation, and classical eyeblink conditioning in alert behaving mice. J Neurosci 32:17431-17441. CrossRef Medline

Guan Z, Giustetto M, Lomvardas S, Kim JH, Miniaci MC, Schwartz JH. Schwartz JH, Thanos D, Kandel ER (2002) Integration of long-termmemory-related synaptic plasticity involves bidirectional regulation of gene expression and chromatin structure. Cell 111:483-493. CrossRef Medline

Guan Z, Kim JH, Lomvardas S, Holick K, Xu S, Kandel ER, Schwartz JH (2003) p38 MAP kinase mediates both short-term and long-term synaptic depression in Aplysia. J Neurosci 23:7317-7325. Medline

Hai T, Hartman MG (2001) The molecular biology and nomenclature of the activating transcription factor/cAMP responsive element binding family of transcription factors: activating transcription factor proteins and homeostasis. Gene 273:1-11. CrossRef Medline

Han JH, Kushner SA, Yiu AP, Cole CJ, Matynia A, Brown RA, Neve RL, Guzowski JF, Silva AJ, Josselyn SA (2007) Neuronal competition and selection during memory formation. Science 316:457-460. CrossRef Medline

Han JH, Kushner SA, Yiu AP, Hsiang HL, Buch T, Waisman A, Bontempi B, Neve RL, Frankland PW, Josselyn SA (2009) Selective erasure of a fear memory. Science 323:1492-1496. CrossRef Medline

Hu JY, Schacher S (2014) Persistent long-term facilitation at an identified synapse becomes labile with activation of short-term heterosynaptic plasticity. J Neurosci 34:4776-4785. CrossRef Medline

Hu JY, Meng X, Schacher S (2002) Target interaction regulates distribution and stability of specific mRNAs. J Neurosci 22:2669-2678. Medline

Hu JY, Goldman J, Wu F, Schacher S (2004) Target-dependent release of a presynaptic neuropeptide regulates the formation and maturation of specific synapses in Aplysia. J Neurosci 24:9933-9943. CrossRef Medline

Hu JY, Chen Y, Bougie JK, Sossin WS, Schacher S (2010) Aplysia cell adhesion molecule and a novel protein kinase $\mathrm{C}$ activity in the postsynaptic neuron are required for presynaptic growth and initial formation of specific synapses. J Neurosci 30:8353-8366. CrossRef Medline

Hu JY, Baussi O, Levine A, Chen Y, Schacher S (2011) Persistent long-term synaptic plasticity requires activation of a new signaling pathway by additional stimuli. J Neurosci 31:8841-8850. CrossRef Medline

Hu Y, Lund IV, Gravielle MC, Farb DH, Brooks-Kayal AR, Russek SJ (2008) Surface expression of GABAA receptors is transitionally controlled by the interplay of cAMP-response element-binding protein and its binding partner inducible cAMP early repressor. J Biol Chem 283:9328-9340. CrossRef Medline

Hughes P, Dragunow M (1995) Induction of immediate-early genes and the control of neurotransmitter-regulated gene expression within the nervous system. Pharmacol Rev 47:133-178. Medline

Josselyn SA, Kida S, Silva AJ (2004) Inducible repression of CREB function disrupts amygdala-dependent memory. Neurobiol Learn Mem 82:159163. CrossRef Medline

Kaang BK, Kandel ER, Grant SG (1993) Activation of cAMP-responsive genes by stimuli that produce long-term facilitation in Aplysia sensory neurons. Neuron 10:427-435. CrossRef Medline

Kandel ER (2012) The molecular biology of memory: cAMP, PKA, CRE, CREB-1, CREB-2, and CPEB. Mol Brain 5:14. CrossRef Medline

Kida S, Josselyn SA, Peña de Ortiz S, Kogan JH, Chevere I, Masushige S, Silva AJ (2002) CREB required for the stability of new and reactivated fear memories. Nat Neurosci 5:348-355. CrossRef Medline

Kim J, Kwon JT, Kim HS, Josselyn SA, Han JH (2014) Memory recall and modifications by activating neurons with elevated CREB. Nat Neurosci 17:65-72. CrossRef Medline

Lai KO, Zhao Y, Ch'ng TH, Martin KC (2008) Importin-mediated retrograde transport of CREB2 from distal processes to the nucleus in neurons. Proc Natl Acad Sci U S A 105:17175-17180. CrossRef Medline

Lamprecht R, Hazvi S, Dudai Y (1997) cAMP response element-binding protein in the amygdala is required for long- but not short-term conditioned taste aversion memory. J Neurosci 17:8443-8450. Medline 
Lassot I, Ségéral E, Berlioz-Torrent C, Durand H, Groussin L, Hai T, Benarous R, Margottin-Goguet F (2001) ATF4 degradation relies on a phosphorylation-dependent interaction with the $\mathrm{SCF} \beta^{\operatorname{TrCP}}$ ubiquitin ligase. Mol Cell Biol 21:2192-2202. CrossRef Medline

Li Q, Roberts AC, Glanzman DL (2005) Synaptic facilitation and behavioral dishabituation in Aplysia: dependence on release of $\mathrm{Ca}^{2+}$ from postsynaptic intracellular stores, postsynaptic exocytosis, and modulation of postsynaptic AMPA receptor efficacy. J Neurosci 25:5623-5637. CrossRef Medline

Liu RY, Fioravante D, Shah S, Byrne JH (2008) cAMP response elementbinding protein 1 feedback loop is necessary for consolidation of longterm synaptic facilitation in Aplysia. J Neurosci 28:1970-1976. CrossRef Medline

Liu RY, Shah S, Cleary LJ, Byrne JH (2011) Serotonin-and training-induced dynamic regulation of CREB2 in Aplysia. Learn Mem 18:245-249. CrossRef Medline

Lonze BE, Ginty DD (2002) Function and regulation of the CREB family transcription factors in the nervous system. Neuron 35:605-623. CrossRef Medline

Mamiya N, Fukushima H, Suzuki A, Matsuyama Z, Homma S, Frankland PW, Kida S (2009) Brain region-specific gene expression activation required for reconsolidation and extinction of contextual fear memory. J Neurosci 29:402-413. CrossRef Medline

Manseau F, Fan X, Hueftlein T, Sossin W, Castellucci VF (2001) $\mathrm{Ca}^{2+}$ independent protein kinase C Apl II mediates the serotonin-induced facilitation at depressed Aplysia sensorimotor synapses. J Neurosci 21: 1247-1256. Medline

Mohamed HA, Yao W, Fioravante D, Smolen PD, Byrne JH (2005) cAMPresponse elements in Aplysia creb1, creb2 and Ap-uch promoters: implications for feedback loops modulating long-term memory. J Biol Chem 280:27035-27043. CrossRef Medline

Montarolo PG, Goelet P, Castellucci VF, Morgan J, Kandel ER, Schacher S (1986) A critical period for macromolecular synthesis in long-term heterosynaptic facilitation in Aplysia. Science 234:1249-1254. CrossRef Medline

Pittenger C, Fasano S, Mazzocchi-Jones D, Dunnett SB, Kandel ER, Brambilla $R$ (2006) Impaired bidirectional synaptic plasticity and procedural memory formation in striatum-specific cAMP response element-binding protein-deficient mice. J Neurosci 26:2808-2813. CrossRef Medline

Raivich G (2008) c-Jun expression, activation and function in neural cell death, inflammation and repair. J Neurochem 107:898-906. Medline

Rajasethupathy P, Antonov I, Sheridan R, Frey S, Sander C, Tuschl T, Kandel ER (2012) A role for neuronal piRNAs in the epigenetic control of memory-related synaptic plasticity. Cell 149:693-707. CrossRef Medline

Sanyal S, Sandstrom DJ, Hoeffer CA, Ramaswami M (2002) AP-1 functions upstream of CREB to control synaptic plasticity in Drosophila. Nature 416:870-874. CrossRef Medline

Sargin D, Mercaldo V, Yiu AP, Higgs G, Han JH, Frankland PW, Josselyn SA (2013) CREB regulates spine density of lateral amygdala neurons: implications for memory allocation. Front Behav Neurosci 7:209. CrossRef Medline
Schacher S, Montarolo PG (1991) Target-dependent structural changes in sensory neurons of Aplysia accompany long-term heterosynaptic inhibition. Neuron 6:679-690. CrossRef Medline

Schacher S, Wu F, Panyko JD, Sun ZY, Wang D (1999) Expression and branch-specific export of mRNA are regulated by synapse formation and interaction with specific postsynaptic targets. J Neurosci 19:6338-6347. Medline

Schacher S, Wu F, Sun ZY, Wang D (2000) Cell-specific changes in expression of mRNAs encoding splice variants of Aplysia cell adhesion molecule accompany long-term synaptic plasticity. J Neurobiol 45:152-161. CrossRef Medline

Sun ZY, Schacher S (1996) Development of short-term heterosynaptic facilitation at Aplysia sensorimotor synapses in vitro is accompanied by changes in the functional expression presynaptic serotonin receptors. J Neurophysiol 76:2250-2261. Medline

Sun ZY, Kauderer B, Schacher S (1996) Differential distribution of functional receptors for neuromodulators evoking short-term heterosynaptic plasticity in Aplysia sensory neurons. J Neurosci 16:7540-7549. Medline

Sung YJ, Wu F, Schacher S, Ambron RT (2006) Synaptogenesis regulates axotomy-induced activation of c-Jun-activator protein-1 transcription. J Neurosci 26:6439-6449. CrossRef Medline

Tubon TC Jr, Zhang J, Friedman EL, Jin H, Gonzales ED, Zhou H, Drier D, Gerstner JR, Paulson EA, Fropf R, Yin JC (2013) dCREB2-meidated enhancement of memory formation. J Neurosci 33:7475-7487. CrossRef Medline

Upadhya SC, Smith TK, Hegde AN (2004) Ubiquitin-proteasomemediated CREB repressor degradation during induction of long-term facilitation. J Neurochem 91:210-219. CrossRef Medline

Villareal G, Li Q, Cai D, Glanzman DL (2007) The role of rapid, local postsynaptic protein synthesis in learning related synaptic facilitation in Aplysia. Curr Biol 17:2073-2080. CrossRef Medline

Wagatsuma A, Sadamoto H, Kitahashi T, Lukowiak K, Urano A, Ito E (2005) Determination of the exact copy numbers of particular mRNAs in a single cell by quantitative real-time RT-PCR. J Exp Biol 208:2389-2398. CrossRef Medline

Wu F, Schacher S (1994) Pre- and postsynaptic changes mediated by two second messengers contribute to expression of Aplysia long-term heterosynaptic inhibition. Neuron 12:407-421. CrossRef Medline

Yin JC, Del Vecchio M, Zhou H, Tully T (1995) CREB as a memory modulator: induced expression of a dCREB2 activator isoform enhances longterm memory in Drosophila. Cell 81:107-115. CrossRef Medline

Zhou Y, Won J, Karlsson MG, Zhou M, Rogerson T, Balaji J, Neve R, Poirazi P, Silva AJ (2009) CREB regulates excitability and the allocation of memory to subsets of neurons in the amygdala. Nat Neurosci 12:1438 1443. CrossRef Medline

Zhu H, Wu F, Schacher S (1997) Site-specific and sensory neurondependent increases in postsynaptic glutamate sensitivity accompany serotonin-induced long-term facilitation at Aplysia sensorimotor synapses. J Neurosci 17:4976-4986. Medline 